\title{
IAMJ
}

INTERNATIONAL AYURVEDIC MEDICAL JOURNAL

ISSN: 23205091

Impact Factor: 5.344

Review Article

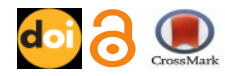

\section{REVIEW ON PRINCIPLES OF FOOD INTAKE IN INDIAN SYSTEM OF MEDICINE}

\author{
Neetu $^{1}$, Ashutosh ${ }^{2}$, P.P. Vyas ${ }^{3}$, Harish Kumar Singhal ${ }^{4}$ \\ ${ }^{1}$ P.G. Scholar, ${ }^{2}$ BAMS,${ }^{3}$ Associate Professor \& Head, ${ }^{4}$ Assistant Professor; \\ P.G. Department of Ayurveda Pediatrics, University College of Ayurveda, \\ Dr. S. R. Rajasthan Ayurved University, Jodhpur, Rajasthan, India
}

Corresponding Author: nsiyag5@gmail.com

\section{https://doi.org/10.46607/iamj3308102020}

(Published online: October 2020)

Open Access

(C) International Ayurvedic Medical Journal, India 2020

Article Received:08/09/2020 - Peer Reviewed:28/09/2020 - Accepted for Publication:05/10/2020

Check for updates

\begin{abstract}
Under the term Nutrition, we think of nutrients and other substances of food that are responsible for maintaining the health, growth, and development of the body. So, it can be said that nutrition is the base of the body as well as life. The existence of human life depends upon nutritional food but the merely intake of nutritional food is not sufficient for proper growth and development. It is equally necessary to know that the nutritional elements required for the body are properly absorbed or not. In the present era, everyone wants to know only about nutritional supplements, but people are not much aware of the rules of food preparation, rules of proper intake, etc. Rules of proper food intake ensure the optimum benefits of the nutritional values of the food. Certain factors which influence the nutritional properties of food are described in Ayurvedic classical texts. This paper deals with the rules of proper food intake mentioned in Kashyap Samhita, Khilasthana, $5^{\text {th }}$ chapter Bhojyopakramaniyadhyay i.e. Atisheeta, Atyushna, Atisnigdha, Ruksha, Atishushka food may cause diseases although these foods may be full of the nutritional substances.
\end{abstract}

Keywords: Nutrition, Atisheeta, Atyushna, Atisnigdha, Ruksha, Atishushka 


\section{INTRODUCTION}

Nutrition means nutrients and other substances of food responsible for maintaining the health, growth, and development of the body. Healthy and nutritional food nourishes the brain, soul, and tissues/cells of the body. Food provides strength, vigor and good complexion not only when it is full of nutritional value but also when it is absorbed properly. According to Indian System of Medicine i.e. Ayurveda, digestion depends upon digestive fire (Jatharagni) which varies in individual to individual. When an individual accepts a good quality food in adequate quantity at proper time then it gets assimilated and digested properly and then nourishes each cell to maintain health. Nowadays, it is very easy to get a quality food under hygienic condition but if it is not taken at proper time, type and quantity along with overlook of food intake principles then it will lead to numbers of disorders in place of nourishment of body. This is the time to consider and follow principles of food intake in day to day life. In this direction various ancient Ayurvedic texts like Charaka Samhita, Sushruta Samhita, Astanga Hridaya and Kashyap Samhita had describe lot of these rules but out of these Acharya Kashyap has described these 24 rules in very detail in his textbook Kasyapa Samhita Khilasthana in chapter five Bhojyopakramaniyadhyay. He says that if all individual follows these principles during dining food then he will never suffer from any ailment. These rules/Vikalpas are-

....... Tasmat Kale SatmyamMatravadushnamSnigdhamavirodhiShuchauDesheShuchishu-

PatreshuShuchiparicharenopaneetamPrangmukhstooshneemstanmanaAasvadayatNatidrutamNativilambitamNatyushnamNatisheetamNatirukshamNatisnigdhamNatibahuNatistokamNatidravam-

NatishushkamNakankshito N Pratanto Naikarasam Va Aarogyayurbalarthi Samashneeyat. (Ka.Khi.5/3)

All these 24 Vikalpas are essential for good health, strength, proper growth and development. The last 13 out of these 24 Vikalpa can cause diseases in individuals. Here these thirteen Vikalpa are discussed in detail.

\section{Material \& Methods}

In this present review manuscript data is compiled from textbook of ancient Indian medicines which are authenticated and supported by various research articles published in international journal search through pubmed, open med, medlar, inmed and google scholar from 1950 to till today.

\section{Ayurveda Concepts}

\section{Atidruta Bhojana ${ }^{1}$ (Fast Eating):-}

Wolfing down food doesn't make please to sense. Human doesn't get proper nutrition and strength from it. Fast \& furious eating causes improper chewing, improper digestion and improper formation of Ahara Rasa (Digestive material). Subsequent level (formation of Dhatu \& Mala) are affected due to absorption of improper Ahara Rasa (Ama). It aggravates all Doshasand causes many types of disorders.

\section{Ativilambita Bhojana ${ }^{2}$ (Slow Eating)}

Acharya Kashyap mentioned the drawbacks of slow eating i.e. overeating, dissatisfaction and indigestion. In slow eating food becomes cold and it doesn't mix properly with digestive juice and doesn't absorb properly. So, it vitiated Annarasa, Dhatu, Mala and aggravates Tridosha.

\section{Atyushna ${ }^{3}$ (Excessive Hot Food)}

According to Acharya Kashyap due to the intake of very hot food a person may get irritation and burning sensation in tongue, throat, lips, heart, and stomach which results mouth ulcer, Mukhpaka \& Akshipaka (Inflammation of mouth and eyes), Visarpa (erysipelas), Raktapitta (urticaria), Bhrama and Jwara (fever). AtyushnaBhojana are full of Ushnata, Langhana, Rukshana ${ }^{5}$, Swedana ${ }^{6}$ properties which mainly generates Amla, Katu and Tikta Rasa ${ }^{7}$.Ushna, Amla and Katu Rasas aggravates Pitta $^{8}$ and produce mainly various types of Pitta JanyaVyadhi

\section{Atisheeta Bhojana9 (Excessive Cold Food)}

According to Acharya Kashyap consumption of AtisheetaBhojana (excessive cold food) increase Kapha, and Vata Dosha that may induce pain, cough and hiccough. Atisheeta Bhojana possess Sheetata, Brinhan ${ }^{10}$, Snehana ${ }^{11}$ and Stambhana ${ }^{12}$ properties. It mainly generates Madhura, Lavan and Kashaya Rasas ${ }^{7}$. It causes 
vitiation of Kapha ${ }^{13}$ and Vata ${ }^{14}$ Doshas. So, this type of food produces Kapha-Vata disorders

\section{Ruksha Bhojana ${ }^{15}$ (Dry Food)}

According to Acharya Kashyap Ruksha Bhojana can induce Vistambha (intestinal obstruction), Udavarta (distension), Vivarnata (discoloration), Glani, overeating, Vata Prakopa, retention of urine. Ruksha Bhojana are full of Langhana ${ }^{4}$, Rukshana $^{5}$, Swedana ${ }^{6}$ and Stambhana ${ }^{12}$ properties. It generates mainly Katu, Tikta, Kashaya Rasas ${ }^{7}$ which plays an important role in vitiation of Vata $^{14}$ Dosha. So RukshaBhojana Produces VataJanyaVyadhiya.

\section{Atisnigdha Bhojana ${ }^{16}$ (Oily food)}

On excessive intake of Atisnigdha Bhojana (oily food) results Tandra, Trishna (thirst), Jeerna Udarroga, Kapha, MedaRoga and Kantha Roga. Due to Atisnigdha Bhojana Snigdhata, Brinhan ${ }^{10}$, Snehana ${ }^{11}$ and Swedana ${ }^{6}$ increases in body which generates Madhura, Amla, Lavana Rasas ${ }^{7}$. It causes vitiation of Vata $^{14}$ and partially Pitta Dosha. So due to AtisnigdhaBhojanaVata - Pitta JanyaVyadhiya Produces in body.

\section{Atibahwashana ${ }^{17}$ (Overeating)}

Acharya Kashyap described side effects of Atibahwashana (overeating) i.e. Vistambha (intestinal obstruction), Udveshtana (cramps in calf muscles with reversed reflex of Apana Vaayu), Klesha (vague pain or distress), Chestahani, Visuchika (dysentery). Atibahwashana causes Agnimandhya and improper $A a-$ hara Rasa which is responsible for Aamotpatti in body. So, this type of food produces mainly Trishoshaja and AamaPradoshajaVyadhiya.

\section{Atistokashina ${ }^{18}$ (Under Eating)}

Under eating can cause Atyangi Vikara, Krashata (emaciation), Bhrama (vertigo), Atrupti, Laghuta (weight loss), Nidranasa (insomnia), Mala \& Mutra Kshaya (diminished urine \& stool). In Atistokashina improper AharaRasa and amount of gastric acid increases so fewer nutrients absorbed by tissue and cells. Dhatus which are responsible for proper growth and development of body does not produce in their proper amount so ultimately Dhatu Kshaya occurs. It also aggravates Tridosha.

\section{Atidravashna ${ }^{19}$ (Liquid Food)}

On consuming excessive liquid food Utklesha (excitement), Bahumutrata (polyuria), Parshwabheda (pain in the side of chest below the armpits), Pratishyaya (cough and cold) and Vidbheda (loose motions). Atidravashna have Snehana ${ }^{11}$, Swedana ${ }^{6}$ and Stambhana ${ }^{12}$ properties which produces Madhura, Amla, And Lavana Rasas. It aggravates Kapha ${ }^{13}$ Dosha and partially Vata ${ }^{14}$ Dosha so Atidravashna Bhojana causes Kapha and Kapha-VataJanya Vyadhiya in human being.

10. Atishushkashana ${ }^{20}$ (Food with little fluid/excessive dry food)

According to Acharya Kashyap on accepting Atishushkashana (food with little fluid/excessive dry food) results in food digested after getting itself bound in the Koshta and RasaDhatu gets dried up resulting in scanty urine and diminished Kapha.

\section{Mohat Bhojanam ${ }^{21}$ (Eating without having no desire to eat)}

According to Acharya Kashyap one who eats despite not having the desire to eat suffers from Avipaka (Indigestion), Aruchi (Anorexia), Vaman (vomiting), Shool (colic pain) and Aanaha (flatulence).

\section{Pratantabhokta ${ }^{22}$ (Repeated eating)}

According to Acharya Kashyap on repletion of food intake prior digestion of previous food will cause Trishna (thirst), Moorcha (fainting), Agnisada (weak digestive fire), Angapida (body ache), Jwar (fever), Kshaya (emaciation), Atisara (loose motions) and Manda Drushti (weak eye sight). Pratantabhokta also causes Agnimandhya and produce improper AharaRa$s a$ which produces Amoptpatti in body.

\section{Ek Rasa Sevana ${ }^{23}$ (Always consuming food of only one rasa)}

According to Acharya Kashyap, people who always consume the one Rasa have weakness (Daurbalyata) and shakiness (Adrudhata).

Agnimandhya (weak digestive fire) is the main steps which occur on not following these principles. If disorders occur, then it can be treated with the drugs that possess Deepan and Pachana quality. Thus, in this way we correct Amadosha and get rid of these disorders. To avoid these disorders which are created due 
to not following food intake principles, everyone should follow all principles of food intake as illustrated by ancient sage along with Pathya Bhojana (wholesome food).

\section{Modern Concepts}

In modern science malpractice of food intake can cause-

* Vitiation of gut hormones which help in regulating appetite.

* Insulin resistance will develop and thus diabetes mellitus.

* High density lipoprotein will decrease which can cause metabolic disorders.

* Overeating releases more gastric acid which can cause ulcers and gastric troubles.

* Ghrelin hormone produced and released mainly by the stomach within small quantity. It is also released by the small intestine, pancreas and brain. This hormone has numerous functions. It is termed the 'hunger hormone' because it stimulates appetite, increases food intake and promotes fat storage. These hormones increase food intake by up to $30 \%$; it circulates in the bloodstream and acts at the hypothalamus, an area of the brain crucial in the control of appetite. Ghrelin has also been shown to act on regions of the brain involved in reward processing such as the amygdala. Level of Ghrelin hormones is regulated by food intake. It rises in the blood just before eating and when fasting, with the timing of these rises being affected by our normal meal routine. Hence, ghrelin is thought to play a role in mealtime 'hunger pangs' and the need to begin meals. Levels of ghrelin increase when fasting (in line with increased hunger) and are lower in individuals with a higher body weight compared with lean individuals, which suggests ghrelin could be involved in the long-term regulation of body weight. Thus, in this way Ghrelin hormone controls hunger and suppresses by gut after a meal. ${ }^{24}$ Glucagon-like peptide-1, oxyntomodulin, peptide YY, cholecystokinin, and pancreatic polypeptide inhibit appetite. ${ }^{25}$ Due to these hormones a person's brain gets the message about the fullness of the stomach.
Therefore, they help a person to stop eating but the above factors affect this process and due to this, a human doesn't get proper satisfaction from food.

\section{DISCUSSION}

It has been observed that every individual consumes often unwholesome food on inappropriate time, quantity and quality such as fast and spicy food, cold drink and cold water resulting in lots of disorders, similar as described earlier by Acharya Kashyapa. In this way, today's trend of fast food is inversely proportional to wholesome \& unwholesome food described in Ayurveda. These types of food are filled with a high amount of carbohydrates which breaks down and released more glucose in the blood at one time. This increases blood sugar level and can causes default in normal insulin responses. Thus, diabetes can occur in younger age. Some fast food like fried pies, pastries, pizza, cookies are full of transfat which increases low density lipoprotein (bad cholesterol) and decrease high density lipoprotein (good cholesterol). These fast foods are rich in salts which rise in blood pressure of individuals due to water retention and also cause life threatening conditions. Other side effect of this excessive intake of fast food produces more calories which can cause obesity. This obesity becomes a root cause of many diseases like breathlessness, asthma, and heart diseases. This type of food contains phthalates chemical which interrupts in work of hormones in the body so it can also induce reproductive problems and birth defects. Food increases acid secretion in stomach and mouth so the risk of impairment tooth's enamel, tooth cavities, stomach ulcer, acidity etc.

\section{CONCLUSION}

On the basis of above description, it is concluded that everyone should follow ancient principles of wholesome \& unwholesome food along with their properties to stay healthy, long and safe disease-free life.

\section{REFERENCES}

1. Bhisagacharya S.S; Kashyap Samhita, Vidyotini Hindi Commentary, Published by Chaukhambha Sanskrit 
Sansthan, Varanasi, Reprinted 2018, Khilasthana Chapter 5/25-26, Page No.391

2. Bhisagacharya S.S; Kashyap Samhita, Vidyotini Hindi Commentary, Published by Chaukhambha Sanskrit Sansthan, Varanasi, Reprinted 2018, Khilasthana Chapter 5/27, Page No.391

3. Bhisagacharya S.S; Kashyap Samhita, Vidyotini Hindi Commentary, Published by Chaukhambha Sanskrit Sansthan, Varanasi, Khilasthana Chapter 5/28-29, Page No.391

4. Pandey K, Chaturvedi Go.; Charak Samhita, Vidyotini Hindi Commentary, Published by Chaukhambha Bharati Academy, Reprinted 2009, Sutrasthana Chapter 22/12, Page No.425

5. Pandey K, Chaturvedi Go.; Charak Samhita, Vidyotini Hindi Commentary, Published by Chaukhambha Bharati Academy, Reprinted 2009, Sutrasthana Chapter 22/14, Page No.425

6. Pandey K, Chaturvedi Go.; Charak Samhita, Vidyotini Hindi Commentary, Published by Chaukhambha Bharati Academy, Reprinted 2009, Sutrasthana Chapter 22/16, Page No.426

7. Pandey K, Chaturvedi Go.; Charak Samhita, Vidyotini Hindi Commentary, Published by Chaukhambha Bharati Academy, Reprinted 2009, Sutrasthana Chapter 26/53-56, Page No.509

8. Pandey K, Chaturvedi Go.; Charak Samhita, Vidyotini Hindi Commentary, Published by Chaukhambha Bharati Academy, Reprinted 2009, Sutrasthana Chapter $1 / 60$, Page No.36

9. Bhisagacharya S.S; Kashyap Samhita, Vidyotini Hindi Commentary, Published by Chaukhambha Sanskrit Sansthan, Varanasi, Reprinted 2018, Khilasthana Chapter 5/30, Page No.391

10. Pandey K, Chaturvedi Go.; Charak Samhita, Vidyotini Hindi Commentary, Published by Chaukhambha Bharati Academy, Reprinted 2009, Sutrasthana Chapter 22/13, Page No.425

11. Pandey K, Chaturvedi Go.; Charak Samhita, Vidyotini Hindi Commentary, Published by Chaukhambha Bharati Academy, Reprinted 2009, Sutrasthana Chapter 22/15, Page No.426

12. Pandey K, Chaturvedi Go.; Charak Samhita, Vidyotini Hindi Commentary, Published by Chaukhambha Bharati Academy, Reprinted 2009, Sutrasthana Chapter 22/17, Page No.426

13. Pandey K, Chaturvedi Go.; Charak Samhita, Vidyotini Hindi Commentary, Published by Chaukhambha Bharati Academy, Reprinted 2009, Sutrasthana Chapter 1/61, Page No.37

14. Pandey K, Chaturvedi Go.; Charak Samhita, Vidyotini Hindi Commentary, Published by Chaukhambha Bharati Academy, Reprinted 2009, Sutrasthana Chapter 1/59, Page No.36

15. Bhisagacharya S.S; Kashyap Samhita, Vidyotini Hindi Commentary, Published by Chaukhambha Sanskrit
Sansthan, Varanasi, Reprinted 2018, Khilasthana Chapter 5/31, Page No.391

16. Bhisagacharya S.S; Kashyap Samhita, Vidyotini Hindi Commentary, Published by Chaukhambha Sanskrit Sansthan, Varanasi, Reprinted 2018, Khilasthana Chapter 5/32, Page No.391

17. Bhisagacharya S.S; Kashyap Samhita, Vidyotini Hindi Commentary, Published byChaukhambha Sanskrit Sansthan, Varanasi, Reprinted 2018, Khilasthana Chapter 5/33, Page No.391

18. Bhisagacharya S.S; Kashyap Samhita, Vidyotini Hindi Commentary, Published by Chaukhambha Sanskrit Sansthan, Varanasi, Reprinted 2018, Khilasthana 5/34, Page No.391

19. Bhisagacharya S.S; Kashyap Samhita, Vidyotini Hindi Commentary, Published by Chaukhambha Sanskrit Sansthan, Varanasi, Reprinted 2018, Khilasthana, Chapter 5/35, Page No.391

20. Bhisagacharya S.S; Kashyap Samhita, Vidyotini Hindi Commentary, Published by Chaukhambha Sanskrit Sansthan, Varanasi, Reprinted 2018, Khilasthana Chapter 5/36, Page No.392

21. Bhisagacharya S.S; Kashyap Samhita, Vidyotini Hindi Commentary, Published By Chaukhambha Sanskrit Sansthan, Varanasi, Reprinted 2018, Khilasthana, Chapter 5/37, Page No.392

22. Bhisagacharya S.S; Kashyap Samhita, Vidyotini Hindi Commentary, Published by Chaukhambha Sanskrit Sansthan, Varanasi, Reprinted 2018, Khilasthana, Chapter 5/38, Page No.392

23. Bhisagacharya S.S; Kashyap Samhita, Vidyotini Hindi Commentary, Published by Chaukhambha Sanskrit Sansthan, Varanasi, Reprinted 2018, Khilasthana, Chapter 5/39, Page No.392

24. Van Der Lely AJ, Tschöp M, Heiman ML, Ghigo E; Biological, physiological, pathophysiological, and pharmacological aspects of ghrelin, Endocr Rev. 2004 Jun; 25(3):426-57.

25. Maralyn R. Druce, Caroline J. Small, Stephen R. Bloom; Mini review: Gut Peptides Regulating Satiety, Endocrinology, Volume 145, Issue 6, 1 June 2004, Pages 2660-2665, https://doi.org/10.1210/en.20040089

\section{Source of Support: Nil \\ Conflict of Interest: None Declared}

How to cite this URL: Neetu et al: Review On Principles Of Food Intake In Indian System Of Medicine. International Ayurvedic Medical Journal \{online\} 2020 \{cited October, 2020 $\quad$ Available from: http://www.iamj.in/posts/images/upload/4783_4787.pdf 